IKONOMIKA: Journal of Islamic Economics and Business

Volume 2, No 2 (2017)

ISSN: 2527-3434 (PRINT) - ISSN: 2527-5I43 (ONLINE)

Page: 162 - I76

\title{
CAPITAL ADEQUACY RATIO AND ITS INFLUENCING FACTORS ON THE ISLAMIC BANKING IN INDONESIA
}

\begin{abstract}
Yolanda
Universitas Borobudur

Indah_eds@yahoo.com

Abstract

Bank is one of the most decisive financial intermediary of a country's economy. Country that in the economies has healthy banking industries will have an impact on all the activity and stability of the economy. The purpose of this study is to investigate the determinants of the capital adequacy of Islamic banks in Indonesia by using panel data of eleven Islamic Banks from 2012 to 2016. This study uses secondary financial data that were analyzed using multiple linear regression model to the capital adequacy of banks (Capital Adequacy Ratio / CAR) as the dependent variable, and profitability (ROA, ROE, NIM) and Liquidity (FDR) as the independent variables. The findings of this study showedpositive correlation between the financial performance of capital adequacy and liquidity. As a result, this study provides more insight into the determinants that affect the capital adequacy of Islamic Banks in Indonesia.
\end{abstract}

Keywords : Profitability, Liquidity, Capital Adequacy Ratio, and panel regression analysis of data.

\begin{abstract}
Abstrak
Bank merupakan salah perantara keuangan yang paling menentukan perekonomian dari suatu Negara. Dan negara yang ekonominya memiliki industri perbankan yang sehat akan berdampak pada semua aktivitas dan stabilitas perekonomiannya. Tujuan dari penelitian ini adalah untuk mengetahui faktor-faktor penentu dari kecukupan modal dari bank-bank syariah di Indonesia dengan menggunakan data panel dari sebelas Bank Umum Syariah mulai tahun 2012 sampai 20I6. Penelitian ini menggunakan data keuangan sekunder dianalisis dengan menggunakan model regresi linier berganda untuk kecukupan modal bank (Capital Adequacy Ratio /CAR) sebagai variable dependen, profitabilitas ( ROA, ROE, NIM) dan Liquidity (FDR) sebagai variable independen. Temuan penelitian ini menunjukkan hubungan positif antara kecukupan modal dengan financial performance dan liquidity. Akibatnya, penelitian ini memberi wawasan lebih dalam tentang faktor penentu yang mempengaruhi kecukupan modal Bank Umum Syariah di Indonesia.
\end{abstract}

Kata Kunci : Profitabilitas , Liquidity, Capital Adequacy Ratio , and panel data regression analysis.

Received :Agustus 26, 20I7- Revised: September 20, 20I7- Accepted: Oktober 26, 2017 Universitas Borobudur

Indah_eds@yahoo.com

DOI: I0.24042/febi.v2iI.943I62I62 


\section{A. INTRODUCTION}

Shariah-based banking established by the Al-Quran (Surah Al-Baqarah (2); 275) that states "... .Allah hath permitted trade and forbidden usury", so that bank that in their activities renounce usury was formed based on guidance of Koran and Islam.

The first Islamic bank in Indonesia is Muamalat Bank. Its establishment is pioneered by the Indonesian Ulama Council and officially operational in 1992.The legal basis for this bank operations using sharia system, then simply accommodated in one paragraph of the "bank sharing system" to the Constitution Law No.7/1992. In 1998, improvements in Constitution Law No.7/I992 into Constitution Law No.I0/1998, explains that there are two banking system in Indonesia (dual banking system), the conventional banking system and Islamic banking system.

The law received acceptance from the banking community, which is marked by the establishment of Islamic business units in conventional banking and then the establishment of Islamic banks. The development of Islamic Banks, Islamic Business Unit and Islamic Rural Banks showed in Table I;

Table I

The development of Islamic Banking Office Network in Indonesia Year 20I2-20I5

\begin{tabular}{|l|c|c|c|c|}
\hline Group & $20 \mathrm{I} 2$ & $20 \mathrm{I3}$ & $20 \mathrm{I} 4$ & $20 \mathrm{I} 5$ \\
\hline Islamic Banks (BUS) & $\mathrm{II}$ & $\mathrm{II}$ & $\mathrm{I} 2$ & $\mathrm{I} 2$ \\
\hline Islamic Business Unit (UUS) & 24 & 23 & 22 & 22 \\
\hline Number of BUS and UUS Offices & 2262 & 2588 & 2483 & $230 \mathrm{I}$ \\
\hline SRB & $\mathrm{I} 58$ & $\mathrm{I} 63$ & $\mathrm{I} 63$ & $\mathrm{I} 63$ \\
\hline
\end{tabular}

Source: FSA report 2015

Islamic banking development that exist now supported by advanced information technology that have been side by side with the development of the existing conventional banks, and according to Tulus Suryanto (2016) technology information is indispensable to improve the performance.

The characteristic of Islamic banking system that operates on the principle of profit sharing system, provides an alternative banking system that is mutually beneficial for the community and the bank. Given the importance of the function and role of Islamic banking in Indonesia, the Islamic banks need to improve the 
performance, particularly in the problem of capital adequacy, in order to create banks with Islamic principles that healthy and efficient.

Islamic bank establishment must be supported by a strong capital. Bank capital is money invested by the owner which intended to finance the bank's business activities in addition to meet the regulations set by the monetary authority. The size of the capital investment of the owners greatly affects the ability of banks to carry out operations. Capital aspect is an assessment of the capital adequacy level of banks to support the risks occurring and proxied by the Capital Adequacy Ratio (CAR). Besides, the capital for the banking aspect is important because large capital strength needed in the global competition. The development of the Islamic banking industry is in line with the domestic and global economic developments which can be seen in Table 2 .

Table 2

Developments Assets, Deposits and CAR of Islamic Banks and Islamic BUssiness Unit Year 20II-20I5

\begin{tabular}{|l|c|c|c|c|c|}
\hline & $20 \mathrm{II}$ & $20 \mathrm{I} 2$ & $20 \mathrm{I3}$ & $20 \mathrm{I} 4$ & $20 \mathrm{I5}$ \\
\hline Assets (trillion USD) & $\mathrm{I} 45.47$ & $\mathrm{I} 95.02$ & 242.28 & 272.34 & 296.26 \\
\hline DPK (trillion USD) & $\mathrm{I} 5.4 \mathrm{I}$ & $\mathrm{I} 47.5 \mathrm{I}$ & $\mathrm{I} 83.53$ & $2 \mathrm{I} 7.86$ & $23 \mathrm{I} .17$ \\
\hline CAR (\%) & $\mathrm{I} 6.63$ & $\mathrm{I} 4.13$ & $\mathrm{I} 4.44$ & $\mathrm{I} 6, \mathrm{I0}$ & $\mathrm{I} 5.02$ \\
\hline
\end{tabular}

Source: Report of the FSA in 2015

The level of national banking capital increased, in 2013 the ratio of Capital Adequacy Ratio (CAR) of $14.44 \%$ increased to $16.10 \%$ in 2014 and in 2015 decreased to $15.02 \%$. Overall the CAR is still above $8 \%$ in accordance with the minimum requirement. This shows Indonesian Islamic banking has enough endurance to anticipate potential risks.

The factors that are affecting the Capital Adequacy Ratio (CAR) includeprofitability, liquidity, and asset growth of the banking system. Profitability is the ratio that measures the level of business efficiency. Profitability ratios used are ROA, ROE and NIM; ROA for example, can take into account the ability of bank management in gaining profit / income (Kashmir, 20I0: 279).Meanwhile liquidity also affects the level of available capital adequacy. Liquidity is a ratio to measure the bank's ability to meet its short term obligations when billed. The liquidity ratio used is Financing Deposit Ratio (FDR). If the growth in the number of loans is greater than the growth in the number of funds raised then the value of 
the bank FDR will be higher. Increasing value of FDR due to growth in the number of loans is higher than the growth in the number of funds rose, so that it will cause a decline in the value of bank's CAR. While Loan to Deposit Ratio (LDR) or Financial to Deposit Ratio (FDR) is a ratio to measure the success / effectivity of bank in its function as an intermediary, according to Bank Indonesia Circular Letter No. I5/4I/Dkmp Dated I October 2013 that the lower limit of the bank LDR set at $78 \%$ (seventy eight percent) and the upper limit is set at $92 \%$. Higher LDR value shows that the bank has managed to (effective to) do as intermediaries.

Other factors affecting the banking capital adequacy is the Asset Growth. Asset growth shows the growth of assets in which assets are assets used for operating assets of the company. Sartono (2009: 248) states that the faster growth of the company, the greater need for funds to finance the expansion. The faster a company grows, so the larger the asset is expected in order to gain greater operational results generated by the company. While Cashmere (20I4) said capital aspect using CAR, liquidity aspect using loan to deposit ratio (LDR), income aspect using return on assets (ROA), net interest margin (NIM) and operational cost to operating income (BOPO) assessed by using financial ratios so as to assess the financial condition of banking companies.

Factors that affect the capital adequacy (Capital Adequacy Ratio / CAR) are widely studied, among them by:

I. Fathiyah Andini and Irni Yunita stated that ROA partially have a significant positive influence on CAR, and NPL and ROE and partially have a significant negative effect on CAR;

2. Nuviyanti and Achmad Herlanto Anggono (20I4), BOPO, LDR and return on equity ratio $(\mathrm{ROE})$ have significant negative effect on the capital adequacy ratio (CAR) and Non-Performing Loan (NPL) ratio and return on assets (ROA) ratio has a positive effect;

3. Bateni, Leila et al obtain the research results that ROA and ROE partially have a significant positive effect on CAR;

4. Büyükşalvarc1, Ahmet, and Abdioğlu, Hasan. (20I I) stated ROE partially has significant negative effect on the CAR;

5. Gustaf Naufan Febrianto and Anggraeni finds that LDR, IPR, NPL, APB, IRR, PDN, FBIR and BOPO simultaneously have a significant influence on the Capital Adequacy Ratio (CAR) ratio, while the $\mathrm{BOPO}$ ratio had a significantly negative effect on Capital Adequacy Ratio (CAR); 
6. Siti Fatimah (20I4), the research declare ROA and FDR have significant negative effect on CAR, while BOPO have positive and significant impact. In addition, there is a long-term relationship between $\mathrm{BOPO}$ and FDR on the CAR and short-term relationship between ROA, BOPO and FDR on CAR;

7. Farah Margaretha and Diana Setiyaningrum (20II), by using Fixed Effect method find that NPL and the size of the bank (SIZE) have no significant effect on the CAR, while the risk of asset returns / risk index (ZRISK), NIM and Liquid Assets to Total deposit (LACSF) have negative and significant impact on the CAR, and the liquidity of liabilities views from Equity to Total liabilities (eQTL) has a positive and significant impact on the CAR;

8. Hendra Fitrianto and Wisnu Mawardi (2006), shows that the NPL, NPA, $\mathrm{ROE}$, and $\mathrm{BOPO}$ does not have significant influence on the CAR, while ROA and LDR have significant effect on CAR;

9. Odunayo M. O.\& Joseph O. A. have proven that from the analysis of the panel data using using Cross-Sectional Specific fixed effect estimations, it is discovered that a direct relationship exists among ETA, ROA and SIZ while an inverse linear relationship that exists among the ROA, CR, DEP and LIQ are statistically significant in Determining the level of capital adequacy among the deposit money banks in Nigeria;

I0. Parvesh Kumar Asphalt and Afroze Nazneen (20I4) research result shows that the capital adequacy ratio (CAR) was negatively related to lending asset quality, asset quality and management quality. However, liquidity and sensitivity are positively correlated;

II. Ali Shingjergjin and Marsida Hyseni (2015), the research results shows profitability indicators such as ROA and ROE do not have an influence on the CAR while NPL, LTD and EM have a significant negative impact towards CAR on the Albanian banking system.

I2. Based on the above results, this study aims to understand the determinants of capital adequacy of Islamic banking and the bank is expected to manage their capital adequacy better. With so the problems examined in this study include;

13. The effect of Return on Assets (ROA), Return on Equity (ROE), Net Operating Margin (NOM), and Financial to Deposit Ratio (FDR) on the Capital Adequacy Ratio (CAR) jointly/simultaneously.

I4. The effect of Return on Assets (ROA), Return on Equity (ROE), Net Operating Margin (NOM), and Financial to Deposit Ratio (FDR) on the Capital Adequacy Ratio (CAR) partially. 


\section{B. LITERATURE REVIEW}

I. Capital Adequacy Ratio (CAR)

Asessment of capital aspect is the assessment of the adequacy of bank capital to cover risk exposure. Capital aspects assessed is the capital assessed by the bank based on Liability for Minimum Capital Adequacy, where the assessment is based on the CAR which has been established by Bank of Indonesia (Kashmir, 2002). CAR magnitude measured from the ratio of equity capital to Risk Weighted Assets (RWA). Systematically, Capital Adequacy Ratio (CAR) can be formulated as follows (according to Bank of Indonesia Circular Letter No. 13/30/DPNP December I6, 20II).

$C A R=\frac{\text { Capital }}{\text { RWA }}$

\section{Return on Assets (ROA)}

According to Rose (2002), ROA is net income divided by total assets. While according to Frianto Pandia (20I2), ROA is an indicator of the banks' ability to make profits on a number of assets owned by the bank. With that, ROA is a ratio showing comparison between profits (before taxes) by total assets, ROA can also reflect the level of asset management efficiency owned. Based on Bank of Indonesia Circular Letter No. I3/30/DPNP December I6, 20I I, Return on Assets (ROA) can be formulated as follows:

ROA $=\frac{\text { Profit before tax }}{\text { Total assets (average) }}$

\section{Return on Equity (ROE)}

Rose (2002) defined return on equity as the net profit compared with the average equity, while Riyadi (2006), stated return on equity is a profitability ratio that indicates the ratio between profit after tax by the bank's core capital, and Lukman Syamsuddin (2009) stated Return on Equity is a measurement of earnings (income) that is available for the owners of the company (both common shareholders and preferred shareholders) on the capital they have invested in the company, so that ROE can be used to measure a company's ability to generate earnings to capitalize the equity that has been invested by shareholders.

In accordance to Bank of Indonesia Circular Letter No. I3/30/DPNP December I6, 20I I, Return onEquity (ROE) can be formulated as follows:

ROE $=\frac{\text { Profit after tax }}{\text { Total equity (average) }}$ 


\section{Net Interest Margin (NIM)}

The main activity of banks is raise community funds and then funnels back to the community. Such activities result in costs and operating income/interest. According to Brock and Suarez (2000), NIM is the difference between the interest income of banks and costs as a percentage of interest earning assets. While Mandos, J and Guevara, J (2004), said NIM is the difference between financial income and financial costs in relation to total assets. In accordance to Bank of Indonesia Circular Letter No. 13/30/DPNP December I6, 201 I, Net Operating Margin (NIM) can be formulated as follows:

$N I M=\frac{\text { Net interest income }}{\text { Average earning assets }}$

\section{Financing Deposit Ratio (FDR) / LDR}

According Dendawijaya (2005), LDR states how much the bank's ability to repay depositors withdrawal of funds committed by relying on loans as a source of such liquidity. With that, liquidity of a bank means that the bank has sufficient financial resources available to meet all liabilities (Siamat, 2005). According to Bank of Indonesia standard regulation of LDR is $78 \%-92 \%$ and on I August 2015 the upper limit changed into 94\% (PBI No. I7/II/PBI/20I5 dated June 25, 20I5). In accordance to Bank of Indonesia Circular Letter No. I3/30/DPNP December I6, 20I I, Financing Deposit Ratio (FDR) / LDR can be formulated as follows:

$$
F D R=\frac{\text { Credit }}{\text { Third party funds }}
$$

\section{Framework}

Based on the formulation of the problem described above regarding the variables that affect the Capital Adequacy Ratio (CAR) of the Islamic Bank in Jakarta, Indonesia within the period of 2012-2016, the theoretical framework presented in this study are described in Figure I:

Figure I

Framework

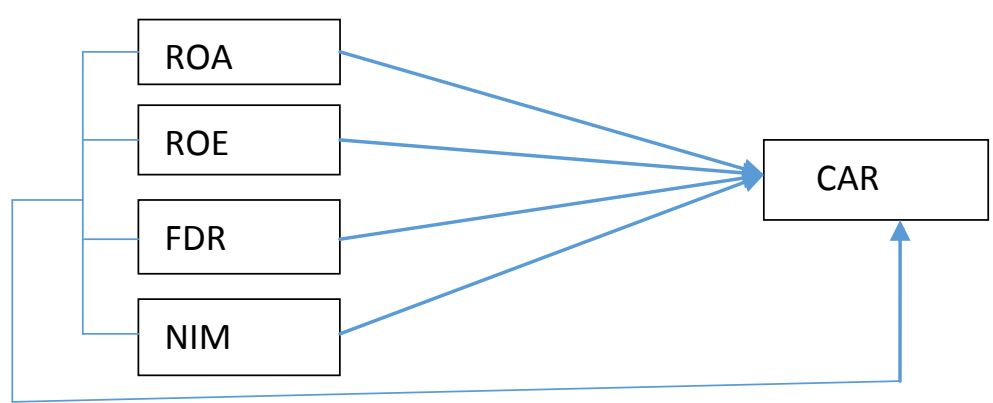

https://ejournal.radenintan.ac.id/index.php/ikonomika

E-mailikonomika_submission@radenintan.ac.id 
Information:

ROA = Return on Assets; ROE = Return on Equity; NIM = NetInterest Margin;

FDR $=$ Financial to Deposid ratio; CAR $=$ Capital Adequacy Ratio

\section{Hypothesis}

Based on the above problems and framework, the hypotheses of this study are as follows:

a. Effect of Return on Assets (ROA) on the Capital Adequacy Ratio (CAR) is positive and significant.

b. Effect of Return on Equity (ROE) on the Capital Adequacy Ratio (CAR) is positive and significant.

c. Effect of Net Interest Margin (NIM) on the Capital Adequacy Ratio (CAR) is positive and significant.

d. Effect of Financial influence to Deposit Ratio (FDR) on the Capital Adequacy Ratio (CAR) is positive and significant.

\section{RESEARCH METHODS}

The purpose of this study was to determine the factors that affect the capital adequacy of Islamic Banks in Indonesia and its influence on financial performance and liquidity. Secondary data was collected from financial statement data of II Islamic Banks in Indonesia. The study covers a period of 5 years starting from the year 2012 until 2016.

Data analyzing technique using Eviews software and the test used are: descriptive statistics, classical assumptions test, hypothesis test using F-test and Ttest and Chow test, multiple linear regression (Panel data Regression Equations using One Way Model)and the final test, coefficient determination test. For more on the above analysis techniques are:

I. Descriptive analysis technique is to describe the results of the study variables (Syofian Siregar, 2012)

2. Classical assumption test

3. This test consists of normality test, Multicolinearity test, Heteroskidastity and autocorrelation. The aim is to provide assurance that the regression equation obtained has accuracy in estimation, unbiased and consistent.

4. Hypothesis test

5. Unison Test (F-Test)

6. To see or examine whether jointly/simultaneously the independent variables (ROA, ROE, NIM, FDR) towards the dependent variable CAR

7. Partial test (T-Test) 
IKONOMIKA

Volume 2, No 2(2017)

8. To see or examine partial of the independent variable (ROA, ROE, NIM, FDR) towards the dependent variable CAR

9. Chow test test test and Hausman

I0. A tool for testing the equality of coefficients test or coefficient equality test, and the test was invented by Gregory Chow.

II. Regression

I2. $=\alpha+\beta$ IXI $+\beta 2 \mathrm{X} 2+\beta 3 \mathrm{X} 3+\beta 4 \mathrm{X} 4+\mathrm{Ei}$.

I3. Information:

I4. $\mathrm{Y}=\mathrm{CAR} ; \mathrm{XI}=\mathrm{ROA} ; \mathrm{X} 2=\mathrm{ROE} ; \mathrm{X} 3=\mathrm{NIM} ; \mathrm{X} 4=\mathrm{FDR}$

I5. $\alpha=$ Constant; $\beta \mathrm{I}-\beta 6=$ Regression Coefficients

16. Coefficient of Determination

17. The coefficient of determination test aims to see how much percentage of the influence of independent variables on the dependent variable.

\section{RESULTS AND DISCUSSION}

Based on the Classical Assumptions test:

I. Normality testwith Jarque Berahistogram test obtainthe probability value of 0.4264 so that the data are normally distributed.

2. Multicollinearity test using Correlation Matrix tests. By using the correlation matrix, in which all variables have a correlation value below 0.80 . It is claimed that this regression model contains no multicollinearity problems.

3. Heteroscedasticity test using ARCH test, where the Probability Chi-squared value is 0.9273 (greater than 0.05). Concluded that the equation regression model is free from heteroscedasticity symptom.

4. Autocorrelation test usingLangrange-Multiplier Test with the Probability Chisquared $0.907 \mathrm{I}$ is greater than 0.05 . It canbe concluded that the regression model is free from autocorrelation problem.

Estimating parameters model with panel data by Widarjono (2007), there are three techniques (models) tht are often offered, namely: common effet, fixed effect and random effect. Widarjono (2007) determines the most appropriate technique in estimating panel data parameter whether using Commom Effect method or Fixed Effect methods is using Chow Test and continue using the Hausman Test. Based on the Chow test and Hausman test results, the chosen method is the fixed effect.

With the selection of the final model using Fixed Effect Model Method, the panel data regression results are as follows; 
Capital Adequacy Ratio And Its Influencing Factors On The Islamic Banking In Indonesia (Yolanda)

Table I

Panel Data Regression

\begin{tabular}{|c|c|c|c|c|}
\hline \multicolumn{3}{|c|}{ Dependent Variable: CAR? } & & \\
\hline \multicolumn{5}{|c|}{ Total pool (balanced) observations: 55} \\
\hline Variable & $\begin{array}{c}\text { Coefficien } \\
t\end{array}$ & Std. Error & \begin{tabular}{|c|}
$\mathrm{t}-$ \\
Statistic
\end{tabular} & Prob. \\
\hline $\mathrm{C}$ & $6.4548 \mathrm{I} I$ & 0.884327 & $\begin{array}{c}7.299 \mathrm{I} 2 \\
3\end{array}$ & 0.0000 \\
\hline ROA? & 0.063902 & 0.012791 & $\begin{array}{c}4.99570 \\
2\end{array}$ & 0.0000 \\
\hline ROE? & $0.00684 \mathrm{I}$ & 0.002938 & $\begin{array}{c}2.32823 \\
4\end{array}$ & 0.0250 \\
\hline FDR? & $0.858 \mathrm{I} 57$ & 0.210120 & $\begin{array}{c}4.084 \mathrm{I} 3 \\
5\end{array}$ & 0.0002 \\
\hline NIM? & 0.213995 & 0.092972 & $\begin{array}{c}2.30170 \\
3\end{array}$ & 0.0266 \\
\hline \multicolumn{5}{|l|}{$\begin{array}{l}\text { Fixed Effects } \\
\text { (Cross) }\end{array}$} \\
\hline _BCA--C & 0.210806 & _PANIN--C & $\left|\begin{array}{c}0.296 \mathrm{I} 3 \\
0\end{array}\right|$ & \\
\hline _BNI--C & $\begin{array}{c}- \\
0.244950\end{array}$ & $\begin{array}{c}\text { BUKOPIN-- } \\
\text { C }\end{array}$ & $\mid \begin{array}{c}- \\
0.25247 \\
9\end{array}$ & \\
\hline _MANDIRI--C & $\begin{array}{c}- \\
0.432190\end{array}$ & _BJB--C & $\mid \begin{array}{c}0.01507 \\
4\end{array}$ & \\
\hline $\begin{array}{c}\text { _MUAMALAT-- } \\
\text { C }\end{array}$ & $\begin{array}{c}- \\
0.319489\end{array}$ & $\begin{array}{c}\text {-VICTORIA } \\
--\mathrm{C}\end{array}$ & $\begin{array}{c}- \\
0.20063 \\
5\end{array}$ & \\
\hline _BRI--C & $\begin{array}{c}- \\
0.266049\end{array}$ & $\begin{array}{c}\text { MAYBANK } \\
\text {--C }\end{array}$ & $\begin{array}{c}1.49795 \\
8\end{array}$ & \\
\hline _MEGA--C & $\begin{array}{c}- \\
0.304 I 77\end{array}$ & & & \\
\hline
\end{tabular}




\begin{tabular}{|l|l|l|c|}
\hline & Effects Specification & & \\
\hline \multicolumn{2}{|l|}{ Cross-section fixed (dummy variables) } & \\
\hline R-squared & 0.913498 & F-statistic & $\begin{array}{c}30.1726 \\
0\end{array}$ \\
\hline $\begin{array}{l}\text { Adjusted R- } \\
\text { squared }\end{array}$ & 0.883222 & Prob(F-statistic) & $\begin{array}{c}0.00000 \\
0\end{array}$ \\
\hline
\end{tabular}

Source: Results of calculation

Hypothesis testing results; Results of F-statistic test obtained significance probability value of $0.0000 \leq 0.05$ which means significant effect, and it indicates that ROA, ROE, FDR and NIM simultaneously has a significant influence on CAR. While from the partial test obtained:

I. ROA affect CAR.

2. The result of the statistical calculation shows significant results and the ROA probability value smaller than $\alpha(0.0000 \leq 0.05)$, the ROA variable has significant and positive impact on CAR. These results are consistent with research fromMohammed T. Abusharba (2013), Leila Bateni et al (20I4),Nuviyanti and Achmad Herlanto Anggono (20I4), Peter Kariuki and Fredrick Olanga Wang'ombe Wafula (2016), and Rafet Aktas et al (2015). While Siti Norbaya Yahaya et al (2016) suggest a negative and significant effect in Japan.

3. ROE affect CAR.

4. The results of the statistical calculation showed significant effect on the value of $\mathrm{ROE}$ probability that smaller than $\alpha(0.0250 \leq 0.05)$, concludes the $\mathrm{ROE}$ variables has significant and positive impact on CAR. These results are in line with Siti Norbaya Yahaya et al (2016), but contrary with toljaz Hussain Bokhari and Syed Muhamad Ali (20I2) that finds the influence of the ROE is not significant on CAR for the bank in Pakistan. While Leila Bateni et al (20I4) andNuviyanti and Achmad Herlanto Anggono (20I4) states it has significant and negative effect.

5. FDR affect CAR.

6. The results of the statistical calculation showed significant effect on FDR probability value that smaller than $\alpha(0.0002 \leq 0.05)$, so that the FDR variable has significant and positive impact on CAR. The results are consistent with Mohammed T. Abusharba (20I3)andNuviyanti and Achmad Herlanto Anggono(20I4) research results reported a significant and negative effect. 
7. NIM affects CAR.

8. The results of the statistical calculation showed significant effect on NIM probability value that smaller than $\alpha(0.0266 \leq 0.05)$, then the NIM variable has significant and positive impact on CAR. While the research results of Nuviyanti and Achmad Herlanto Anggono (2014) showed negative and significant effect at $\alpha=0.10$. Pamuji Raharjo Gesang (20I4) suggests the influence of NIM on CAR is negative and insignificant.

Based on the coefficient determination test $\left(R^{2}\right)$, the Adjusted $R^{2}$ values obtained by0.883222, which shows that 88.32 percent of the CAR variation can be explained byfour (4) independent variables variation, namely ROA, ROE, FDR and NIM. While the rest of II.68 percent is explained by other variables that not examined.

\section{E. CONCLUSION}

This study sought to investigate the relationship between earnings (ROA, ROE, NIM) and Liquidity (FDR) of commercialIslamic banking in Indonesia with a capital adequacy ratio (CAR). Secondary data comes from the annual report of Islamic banks that have been published. The study covers five years from 2012 to 2016 with a total of 55 observations. Three (3) variables are used to represent financial performance, while one (I) variable representing Liquidity.

Regression analysis showed various signs of relationship between variables that slightly different from the theories, for example, based on the theory FDR should be associated with CAR in negative but through this research, the relationship between FDR and CAR is positive. It can be concluded that other factors will also have an impact on commercial Islamic Banks in determining their CAR.

In the further study, additional variables must be tested in order to obtain more comprehensive results. This research is expected to provide more referrals to researchers, especially in the study of Islamic banking and also provide strong evidence to investors and banking institutions about the importance of securing sufficient capital to mitigate banking risks.

\section{REFERENCES}

Ali Shingjergiin and Marsida Hyseni (2015), The Determinants Of The Capital Adequacy Ratio In The Albanian Banking System During 2007 - 20I4, International Journal of Economics, Commerce and Management United Kingdom Vol. III, Issue I, Jan 20I5, p. I-I0.

Aktas, Rafet, Suleyman Acikalin, Bilge Bakin, Gokhan Celik. (2015), The Determinants of Banks' Capital Adequacy Ratio: Some Evidence from South 
Eastern European Countries, Journal of Economics and Behavioral Studies Vol. 7, No. I, February 2015 (ISSN: 2220-6I40), p. 79-88.

Bateni, Leila, Vakilifard, Hamidreza, dan Asghari, Farshid. (20I4). The Influential Factors on Capital Adequacy Ratio in Iranian Banks. International Journal of Economics and Finance, 6(II), p. I08-II6.

Brock, P.L and Suarez, L.R (2000), Understanding the Behavior of Bank Spreads in Latin Amerika, Journal of Development Economics Vol 63, p. II3I34.

Bokhari Hussain Ijaz ,Syed Muhamad Ali and Khurram Sultan (20I2), Determinants Of Capital Adequacy Ratio In An Empirical Analysis From Pakistan Banking Sector, Journal Academy Of Contemporary Research 2012 p. 5-I7.

Büyükşalvarc1, Ahmet., dan Abdioğlu, Hasan. (20II). Determinants of capital adequacy ratio in Turkish Banks: A panel data analysis. African Journal of Business Management, 5(27), I I I99-I I209.

Andini, Fathiyah and Irni Yunita. 2015. Analisis Pengaruh Return On Asset (Roa), Return On Equity (Roe), Non Performing Loan ( $\mathrm{Npl}$ ), Dan Loan To Deposit Ratio (Ldr) Terhadap Capital Adequacy Ratio (Car) Pada Perusahaan Perbankan Di Indonesia (Studi Kasus Pada Bank Umum Indonesia yang Terdaftar di Bursa Efek Indonesia Periode 2009-2013) [The Effect of Return On Asset (ROA), Return on Equity (ROE), Non Performing Loan (NPL), and loan to deposit ratio (LDR) Against Capital Adequacy Ratio (CAR) on The Banking Companies in Indonesia (Case Study On Indonesian Public Bank Listed in Indonesia Stock Exchange Period 2009-2013)], e-Proceeding of Management : Vol.2, No.2 Agustus 2015, p I384-I39I.

Gesang Raharjo Pamuji, Dedi Budiman Hakim, Adler Haymans Manurung, and Tubagus Nur Ahmad Maulana (20I4), Determinant Of Capital Ratio: A Panel Data Analysis On State-Owned Banks In Indonesia, Bulletin of Monetary, Economics and Banking, Volume I6, Number 4, April 20I4, p. 370-385.

Gustaf Naufan Febrianto and Anggraeni (2016), Pengaruh business risk terhadap capital adequacy ratio (CAR) pada Bank Umum Swasta Nasional Devisa go public [The effect of business risk to the capital adequacy ratio (CAR) at the National Private Commercial Bank Foreign Exchange to go public], Journal of Business and Banking ISSN 2088-784I Volume 6 Number I May - October 2016 p. I47- I66

Hendra Fitrianto dan Wisnu Mawardi (2006), Analisis Pengaruh Kualitas Aset, Likuiditas, Rentabilitas, Dan Efisiensi Terhadap Rasio Kecukupan Modal Perbankan Yang Terdaftar Di Bursa Efek Jakarta [Effect Analysis of Asset Quality, Liquidity, Profitability, And Efficiency On Capital Adequacy Ratio of Banking Listed on the Jakarta Stock Exchange], Jurnal Studi Manajemen \& Organisasi Volume 3, Nomor I, Januari, Tahun 2006, p. I-II. 
Kasmir, 2002, Dasar-dasar Perbankan [Banking Datas], PT. Raja Grafindo Persada, Jakarta

Kasmir. 2010. Manajemen Perbankan [Banking Management]. Jakarta: Raja Grafindo Persada

.Kasmir (20I4). Analisis Laporan Keuangan [Financial Statement Analysis]. Depok: PT Raja Grafindo

Parvesh Kumar Aspal dan Afroze Nazneen (20I4), An Empirical Analysis of Capital Adequacy in the Indian Private Sector Banks, American Journal of Research Communication, 2(II): p. 28- 42.

Mandos, J and Guevara, J (2004), Factors Explaining The Intrest Margin In The Banking Sector Of The European Union, Journal Of Banking Finance Elsevier vol. 28, p. 2259-2287.

Margaretha Farah dan Diana Setiyaningrum. (20II), Pengaruh Resiko, Kualitas Manajemen, Ukuran dan Likuiditas Bank terhadap Capital Adequacy Ratio BankBank yang Terdaftar di Bursa Efek Indonesia [Effect of Risk, Management Quality, Size and Bank Liquidity on Capital Adequacy Ratio within Banks Listed in Indonesia Stock Exchange], Jurnal Akuntansi Dan Keuangan, Vol. I3, No. I, Mei 20II, p. 47-56.

Mohammed T. Abusharba, Iwan Triyuwono, Munawar Ismail and Aulia F. Rahman, ( 2013), Determinants of Capital Adequacy Ratio (CAR) in Indonesian Islamic Commercial Banks, Global Review of Accounting and Finance Vol. 4. No. I. March 2013. Pp. I59 - I70

Nuviyanti and Achmad Herlanto Anggono. (20I4) Determinants Of Capital Adequacy Ratio (Car) In 19 Commercial Banks (Case Study : Period 2008 2013), Journal Of Business And Management Vol. 3, No.7, 20I4: p. 752-764

Odunayo Magret Olarewaju \& Joseph Olorunfemi Akande (2016), An Empirical Analysis of Capital Adequacy Determinants in Nigerian Banking Sector, International Journal of Economics and Finance; Vol. 8, No. I2; 2016 p. I32I42.

Pandia, Frianto. (2012). Manajemen Dana dan Kesehatan Bank [Bank's Funds and Health Management]. It ed. Jakarta: Rineka Cipta.

Riyadi, Selamet. 2006. Banking Asset and Liability Management, $3^{\text {rd }}$ ed. Jakarta: Fakultas Ekonomi Universitas Indonesia.

Rose P (2002). Commercial bank management. U.S: McGraw-Hill International Editions

Purnamasari, F., \& Darmawan, A. (2017). Islamic Banking and Empowerment of Small Medium Enterprise. ETIKONOMI, 16(2), 221-230. 
Sartono, A. 2009. Manajemen Keuangan: Teori dan Aplikasi [Financial Management: Theory and Applications.]. $4^{\text {th }}$ ed. BPFE Fakultas Ekonomi UGM. Yogyakarta.

Syamsuddin, Lukman. 2009. Manajemen Keuangan Perusahaan Konsep Aplikasi dalam: Perencanaan, Pengawasan dan Pengambilan Keputusan [The Concept of Corporate Financial Management Applications in Planning, Monitoring and Decision Making]. New ed., Jakarta: Raja Grafindo Persada

Fatimah Siti. 20I4. Pengaruh Rentabilitas, Efisiensi Dan Likuiditas Terhadap Kecukupan Modal Bank Umum Syariah Study Pada PT Bank Syariah Mandiri Tbk. [Effect of Profitability, Efficiency and Liquidity Against Sharia Commercial Bank Capital Adequacy, Study At PT Bank Syariah Mandiri Tbk], Journal of Islamic Economics Volume 6 no. I , Januari 20I4. P. 53-72.

Purnamasari, F., \& Darmawan, A. (2017). Islamic Banking and Empowerment of Small Medium Enterprise. ETIKONOMI, 16(2), 221-230.

Siamat, Dahlan (2005). Manajemen Lembaga Keuangan [Management of Financial Institutions]. $4^{\text {th }}$ ed., Jakarta: Badan Penerbit Fakultas Ekonomi Universitas Indonesia.

Siti Norbaya Yahaya, Nusaibah Mansor\& Kazuhiro Okazaki. (2016), Financial Performance and Economic Impact on Capital Adequacy Ratio in Japan, International Journal of Business and Management; Vol. II, No. 4; 20I6, p. I42I.

Syofian Siregar, 2012, Statistik Parametrik Untuk Penilaian Kuantitatif: Dilengkapi perbandingan Perhitungan Manual dan SPSS [Parametric Statistics for Quantitative Assessment: Equipped with Comparison of Manual and SPSS Calculation], Jakarta: PT Bumi Aksara

Suryanto Tulus, (2016), Dividend Policy, Information Technology, AccountingReporting to Investor Reaction and Fraud Prevention, International Journal of Economic Perspectives, 20I6, Volume I0, Issue I, p. I38-I50.

Widarjono, Agus (2007). Ekonometrika: Teori dan Aplikasi Untuk Ekonomi dan Bisnis [Econometrics: Theory and Applications to Economics and Business], $2^{\text {nd }}$ ed., Yogyakarta: Ekonisia FE Universitas Islam Indonesia.

Wang'ombe Kariuki Peter and Olanga Wafula Fredrick. (2016), Capital Adequacy and Financial Performance of Deposit Taking Saving and Credit Cooperative Societies in Kenya, The International Journal Of Business \& Management (ISSN 232I-89I6), Vol 4 Issue 9 September, 20I6, p. 20-25. 